\title{
Fish Diversity in Three Lentic Water Bodies of Shivamogga District, Karnataka: A Comparative Study
}

\author{
Dr. K. L. Naik ${ }^{1}$, Dr. B. R. Kiran ${ }^{2}$ \\ ${ }^{1}$ Department of Zoology, Sahyadri Science College (Autonomous), Shivamogga, Karnataka \\ ${ }^{2}$ Research \& Teaching Assistant in Environmental Science, DDE, Kuvempu University, Shankaraghatta, \\ Karnataka
}

*Corresponding Author: Dr.B.R.Kiran, Research \& Teaching Assistant in Environmental Science, DDE, Kuvempu University, Shankaraghatta, Karnataka

\begin{abstract}
The fish diversity and abundance of three lentic water bodies (Sogane tank, Navule tank and Tunga reservoir) were studied by monthly samples taken from February to September 2015. In this study, Sogane tank supported 16 fish species belonging to 05 orders, 08 families and 11 genera. While, Navule tank supported 13 fish species belonging to 03 orders, 06 families and 12 genera. However, Tunga reservoir supported 32 fish species belonging to 06 orders, 11 families and 18 genera. Among all the water bodies regarding fish families Cyprinidae was dominant. The study of fish fauna is useful for planning of fisheries development. Hence, proper management and utilization of this fish wealth is necessary to take up the sustainable steps to monitor and conserve fishes in these water bodies.
\end{abstract}

Keywords: Biodiversity status, Fish fauna, Sogane tank, Navule tank, Tunga reservoir, Shivamogga district

\section{INTRODUCTION}

Many fish species have become highly endangered, where heavy demand is placed on freshwater. However, the impact of the anthropogenic activities, habitat degradation, exotic species introduction, water diversions, pollution and global climate change are the main causative agents for the aquatic species rapid decline. Reservoirs play a very important role in the geochemical cycling of elements and influence the chemical composition and material transfer of the river system (Abhay et al., 2005). They are of high ecological, economic and recreational importance (Carol et al., 2006). They contribute significantly in fulfilling the basic human needs such as water for drinking and industrial use, irrigation, flood control, hydro power generation, inland navigation, fishing and recreation (Basavaraja et al., 2014).

The balance in food chain may be affected due to pollution in aquatic system. In addition, there are many threats to fish diversity such as construction of dam, which block the spawning migrations and introduction of exotic species and over fishing. Therefore, knowing the status of fish fauna is indispensible to prevent the loss of particular species (Ramanjaneya and Ganesh, 2016).

The main objective of present investigation was to give recent data regarding fish diversity in relation to abundance and diversity status of three lentic aquatic system, aiming to contribute a better knowledge of the fish diversity profile of the water bodies of Shivamogga district and a tool for conservation planning of aquatic environments.

\section{Materials AND Methods}

\subsection{Study Area}

Sogane tank is situated at Latitude of $13^{\circ}, 55^{\prime} \mathrm{N}$, Longitude $75^{\circ}, 50^{\prime} \mathrm{E}$ in the Shivamogga city at the distance of $10 \mathrm{~km}$. Field investigation was carried out for a period of eight months from February 2015 to September 2015. The Navule tank acquires a land of 26 hectares and depth of the tank is about 6-7 ft. The Tunga reservoir is a major tributary of Tungabhadra river in Shivamogga district of Karnataka. This reservoir is located at $75^{\circ} 40^{\prime} 20^{\prime \prime} \mathrm{E}$ longitude and $14^{\circ} 0{ }^{\prime} 24^{\prime \prime} \mathrm{N}$ latitudes and the total water spread area is about 1600 ha. 


\subsection{Fish Sampling}

Fishes were collected monthly during February to September 2015 by using monofilament and multifilament gill nets of various mesh sizes ranging from 6-15 mm. The dragnets, scoop nets and cast nets are used to catch the fishes. Fishes were identified as per Jayaram (1999) and Talwar and Jhingran(1991).

\section{RESULTS AND DISCUSSION}

A total of 38 species of fishes were recorded. Of which, Sogane tank supported 16 fish species belonging to 05 orders, 08 families and 11 genera. Though Navule tank supported 13 fish species belonging to 03 orders, 06 families and 12 genera. However, Tunga reservoir supported 32 fish species belonging to 06 orders, 11 families and 18 genera. The biodiversity status of fishes of the three water bodies are depicted in Figure 1 to 3 .

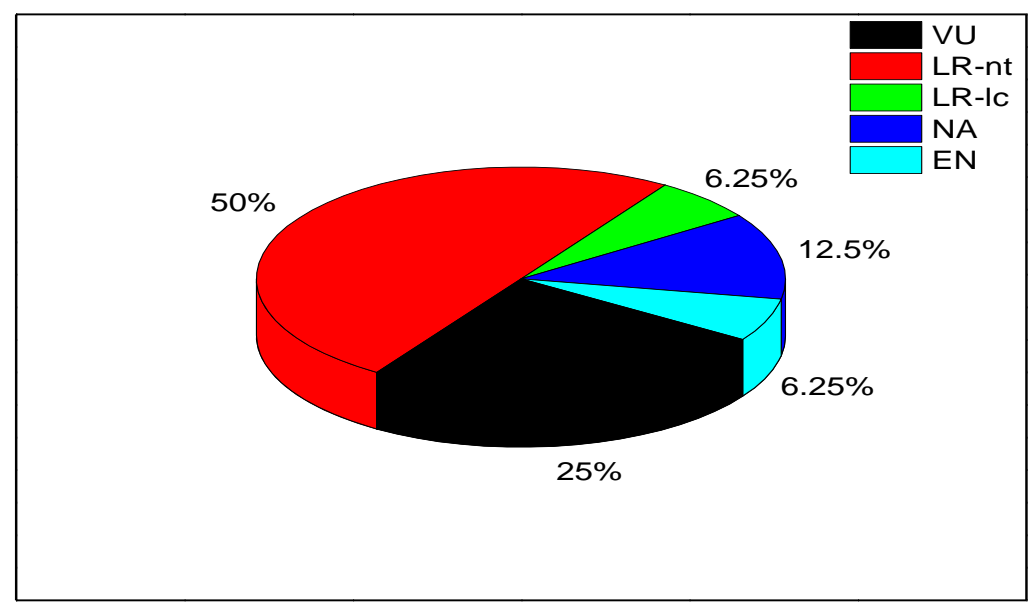

Figure1. Biodiversity status (IUCN-1994) of fishes of Sogane tank

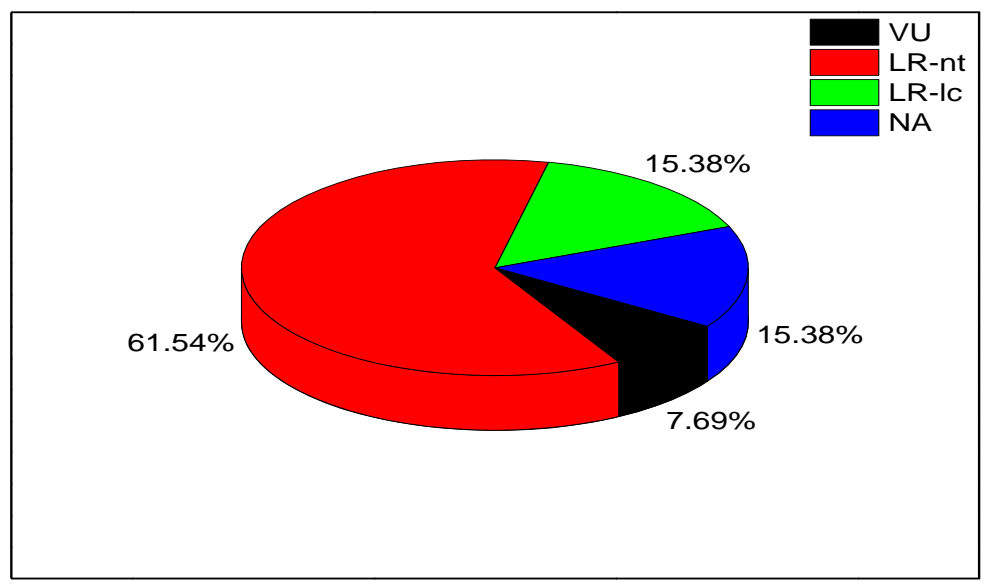

Figure2. Biodiversity status of fishes in Navule tank

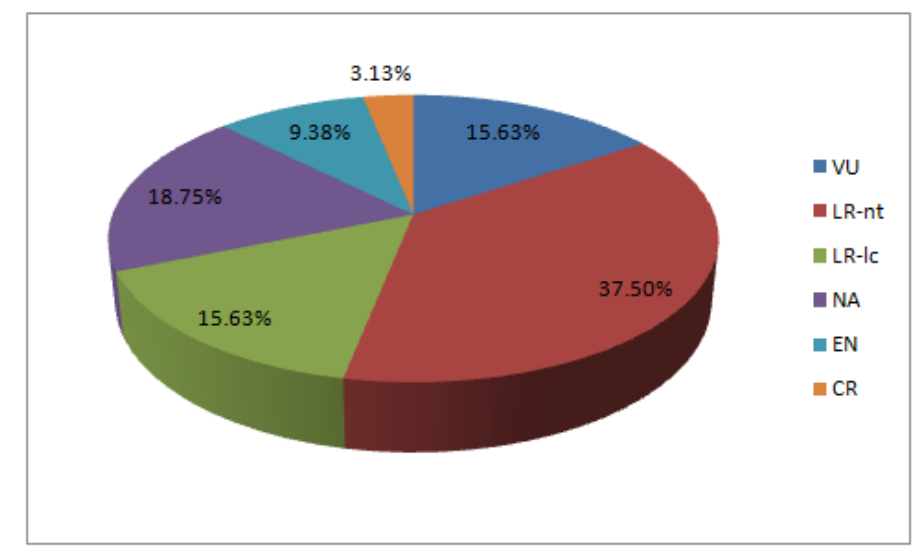

Figure3. Biodiversity status of fishes in Tunga reservoir 
Among the fish families Cyprinidae was most dominant in three water bodies (Figure 4; Table 1). This indicates good correlation with overall species richness across the sites and could be utilized by the biodiversity conservation managers for prioritization of sites of conservation and habitat restoration (Bergerot et al. 2008). The fish species recorded in three water bodies are economically important and having high commercial significance.

The fishes are categorized in to herbivores, carnivores and omnivores. In these water bodies almost all fishes recorded are useful as food fishes and Salmostoma, Rasbora, Puntius species are used for ornamental purpose. The present study of fish fauna in three water bodies showed that most of the fish species recorded were widely distributed in the lotic water bodies of Western Ghats. In this study cyprinid fishes were dominant. Therefore, the present investigation indicates that cyprinid fishes are found to be the more dominant group than others which is supported by other studies also (Singh et al., 2006).

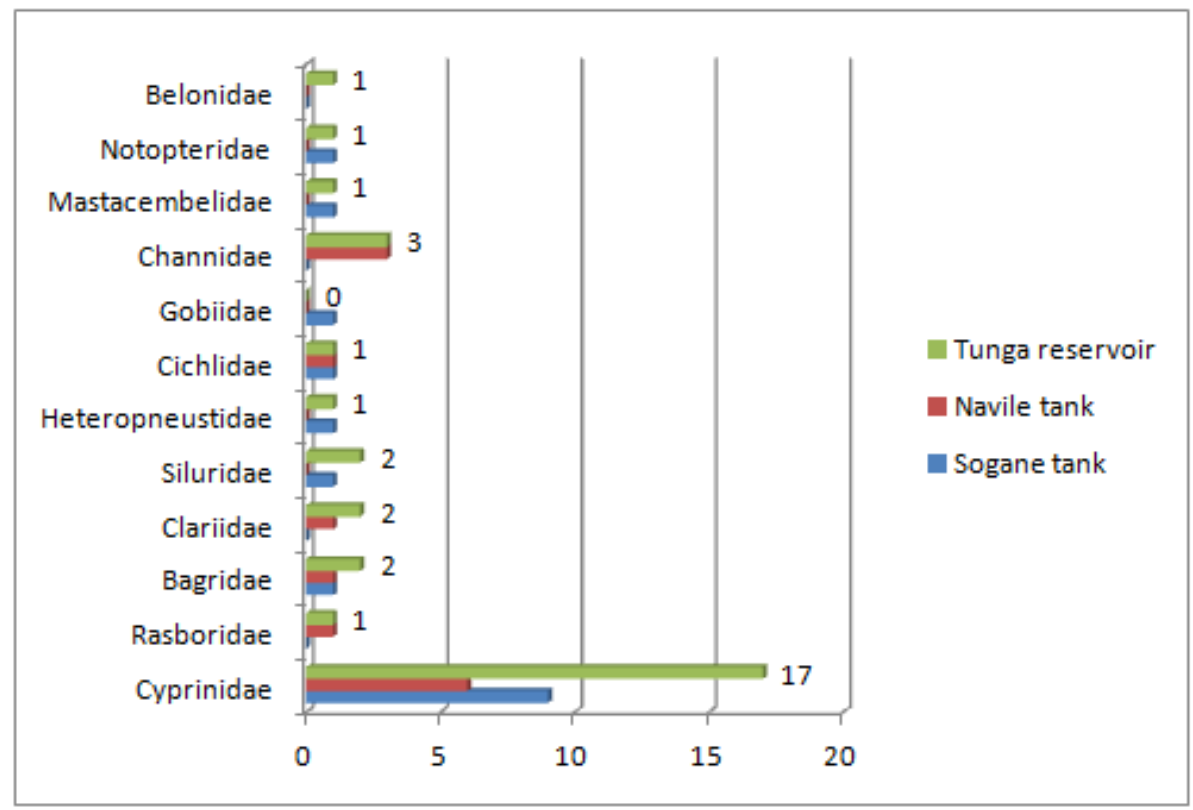

Figure4. Diagrammatic representations of the number contribution of each family in three water bodies

Table1. Fish abundance and Biodiversity status in three lentic water bodies of Shivamogga district, Karnataka

\begin{tabular}{|c|c|c|c|c|c|}
\hline Scientific Name & Abundance & \begin{tabular}{|l} 
Biodiversity \\
status
\end{tabular} & $\begin{array}{c}\text { Sogane } \\
\text { tank }\end{array}$ & $\begin{array}{c}\text { Navule } \\
\text { tank }\end{array}$ & $\begin{array}{c}\text { Tunga } \\
\text { reservoir }\end{array}$ \\
\hline \multicolumn{6}{|l|}{ I. Order:Cypriniformes Family: Cyprinidae } \\
\hline Salmostoma untrahi & A-2 & NA & - & + & - \\
\hline Catla catla & A-(3-4) & VU & + & + & + \\
\hline Cirrhinus fulungee & A (3-4) & LR-nt & + & - & - \\
\hline C. mrigala & A-2 & LR-nt & + & + & + \\
\hline C.cirrhosa & A-2 & VU & - & - & + \\
\hline C.reba & $\mathrm{A}(3-4)$ & VU & + & - & - \\
\hline Labeo rohita & A-2 & LR-nt & + & + & + \\
\hline L.calbasu & A-2 & LR-nt & + & - & + \\
\hline L.bata & A-1 & LR-Ic & - & - & + \\
\hline L.fimbriatus & A-2 & LR-Ic & - & - & + \\
\hline L.gonius & A-2 & LR-Ic & - & - & + \\
\hline L.kontius & A-1 & EN & - & - & + \\
\hline Cyprinus carpio & A-2 & LR-Ic & + & + & + \\
\hline Puntius ticto & A-2 & LR-nt & - & - & + \\
\hline Puntius $s p$ & A (3-4) & NA & + & - & + \\
\hline P.chola & A (3-4) & VU & + & - & - \\
\hline P.filamentosus & A-2 & NA & - & - & + \\
\hline P.sarana & $\mathrm{A}-2$ & VU & - & - & + \\
\hline Ctenopharyngodon idella & $\mathrm{A}(3-4)$ & NA & - & - & + \\
\hline Hypophthalmichthys molitrix & A-2 & LR-nt & - & + & + \\
\hline
\end{tabular}




\begin{tabular}{|c|c|c|c|c|c|}
\hline Tor Sp. & A-0 & CR & - & - & + \\
\hline \multicolumn{6}{|l|}{ Rasboridae } \\
\hline Rasbora daniconius & A-2 & LR-nt & - & + & + \\
\hline \multicolumn{6}{|c|}{ II.Order: Siluriformes Family: Bagridae } \\
\hline Mystus cavasius & A-(3-4) & LR-nt & + & + & - \\
\hline Sperata aor & A-2 & VU & - & - & + \\
\hline S.seenghala & A-2 & NA & - & - & + \\
\hline \multicolumn{6}{|l|}{ Family-Clariidae } \\
\hline Clarias batrachus & A-1 & LR-lc & - & + & + \\
\hline Wallago attu & A-1 & LR-nt & - & - & + \\
\hline \multicolumn{6}{|l|}{ Family: Siluridae } \\
\hline Ompok bimaculatus & A-2 & EN & - & - & + \\
\hline O.pabo & A-2 & EN & + & - & + \\
\hline \multicolumn{6}{|l|}{ Family: Heteropneustidae } \\
\hline Heteropneustes fossilis & A (3-4) & VU & + & - & + \\
\hline \multicolumn{6}{|c|}{ III.Order: Perciformes Family: Cichlidae } \\
\hline Oreochromis mossambica & A-(3-4) & NA & + & + & + \\
\hline \multicolumn{6}{|l|}{ Family: Gobiidae } \\
\hline Glossogobius giuris & A-(3-4) & LR-nt & + & - & - \\
\hline \multicolumn{6}{|l|}{ Family: Channidae } \\
\hline Channa marulius (Ham-Buch) & A-2 & LR-nt & - & + & + \\
\hline C. punctatus & A-2 & LR-nt & - & + & + \\
\hline C.striatus & A-1 & LR-nt & - & + & + \\
\hline \multicolumn{6}{|l|}{$\begin{array}{l}\text { IV. Order :Cyprinodontiformes } \\
\text { Family: Mastacembelidae }\end{array}$} \\
\hline Mastacembalus armatus & A-(3-4) & LR-nt & + & - & + \\
\hline \multicolumn{6}{|l|}{$\begin{array}{l}\text { V.Order: Osteoglossiformes } \\
\text { Family: Notopteridae }\end{array}$} \\
\hline Notopterus notopterus & A-(3-4) & LR-nt & + & - & + \\
\hline \multicolumn{6}{|l|}{$\begin{array}{l}\text { VI. Order:Beloniformes } \\
\text { Family:Belonidae }\end{array}$} \\
\hline Xenentodon cancila & A-0 & NA & - & - & + \\
\hline
\end{tabular}

A0-very rare, A1-rare, A2-common, A (3-4) - very common, LR-nt= Lower risk Near threatened; NA-Not assessed, VU-Vulnerable, EN-Endangered ; LR-lc-Lower risk least concern; CR-Critically Endangered; + = Present ; - = Absent

Thirumala and Kiran (2016) worked on the cyprinid fish diversity of three lentic water bodies in relation to physico-chemical parameters in Shivamogga district of Karnataka. They identified 15 cyprinid fish species and as far as biodiversity status (IUCN), is concerned, out of 15 species, 5 species are LR-nt (33.33\%), 2 species as LR- Ic (13.33\%) and NA and VU each with $26.67 \%$ respectively. All fishes are useful as food fishes except Puntius species which are useful as ornamental fishes.

The present fish study has also shown that some of fish species recorded were predatory in nature. Sukumaran and Das (2005) have also made the same observation and stated that majority of the reservoirs of Karnataka state have a large population of predatory fish species.

During study it was found that abundance and diversity of fishes were found to be very high in respect to Tunga reservoir and Sogane tank. The maximum numbers of species were recorded from low land areas. According to Shaikh et al (2011) in low and middle land areas fresh water fish diversity was found to be very high. It is due to deep water bodies allow niche segregation in order to enable the fishes to live without facing more intra and inter specific competitions. During summer when maximum level of water decreased due to hot air and high temperature most of fishes migrated toward low land for survival. But during winter season diversity of fish fauna abundant due to clear water, preference of maximum amount of phyto and zooplankton as complain to rainy season. The presence of exotic species may be due to carriage from nearby water bodies by flood water.

\section{CONCLUSION}

The present study indicates that Tunga and Sogane water bodies are rich in diversified fish fauna consists of native species, economical, cultivable, ornamental and rare species of fishes. Changes in fish community, directly or indirectly affect other components of the aquatic ecosystem including 
physical, chemical and biological characteristics. Habitat loss and ecological degradation has seriously affected the fish fauna. Therefore, a sustainable strategies needs to explore more fish species, utilization and save fish community of these three water bodies. The study will provide future strategies for development and fish conservation. Conservation measures require plantation in catchment area and information on illegal fishing.

\section{REFERENCES}

Abhay Kumar Singh, Mondal GC, Singh PK, Singh S, Singh TB and Tewary BK. 2005. Hydrochemistry of reservoirs of Damodar river basin, India: Weathering processes and Water quality assessment, Environ Geol., 48: 1014-1028.

Basavaraja,D., J.Narayana , B.R.Kiran and E.T.Puttaiah. 2014. Fish diversity and abundance in relation to water quality of Anjanapura reservoir, Karnataka, India. Int.J. Curr. Microbiol. App.Sci 3(3): 747-757.

Bergerot, B.,E. Lasne, T.Vigneron \& P. Laffaille. 2008. Prioritization of fish assemblages with a view to conservation and restoration on a large scale European basin, the Loire (France). Biodiversity Conservation, 17(9):2247-2262.

Carol J, Benejam L, Alcaraz C, Vila- Gispert A, Zamora L, Navarro E, Armengol J and Garcia-Berthou E .2006. The effects of limnological features on fish assemblages of 14 Spanish reservoirs. Ecol Freshw Fish., 15: 66-77.

Jayaram, K.C.1999.The freshwater fishes of the Indian region. Narendra Publishing House, Delhi-06.

Ramanjaneya and Ganesh C. B. Fish faunal diversity in Tungabhadra Reservoir, Hosapete, Ballari District, Karnataka. International Journal of Research in Fisheries and Aquaculture 2016, 6(2): 21-25.

Shaikh HM, Kamble SM and Renge AB .2011. The study of ichthyofauna diversity in Upper Dudhna project water reservoir near Somthana in Jalna district (MS) India. J of Fish and Aqua, 2(1): 08-10.

Singh, S., Omprakash, M., S. Chari and Vardia, H. K.2006. Diversity of fish fauna in catchment of Mahanadi River in Raipur District of Chhattishgarh. Environment \& Ecology, 24 (1), 165-169.

Sukumaran, P.K.and A.K.Das.2005.Limnology and fish production efficiencies of selected reservoirs of Karnataka. Indian J. Fish., 52(1): 47-53.

Talwar PK, Jhingran AG.1991.Inland fishes of India and adjacent countries. Vol 1 \& VII. Oxford \& IBH Publ. Co. Pvt. Ltd; New Delhi.

Thirumala, S and B.R.Kiran. 2016. Occurrence and distribution of cyprinid fishes in three lentic water bodies of Shivamogga district, Karnataka: A comparative study. International Journal for Innovative Research In Multidisciplinary Field Volume 2(11) : 358-361.

Citation: K. L. Naik \& B. R. Kiran, "Fish Diversity in Three Lentic Water Bodies of Shivamogga District, Karnataka: A Comparative Study", International Journal of Research Studies in Biosciences (IJRSB), vol. 5, no. 11, pp. 1-5, 2017. http://dx.doi.org/10.20431/2349-0365.0511001

Copyright: () 2017 Authors. This is an open-access article distributed under the terms of the Creative Commons Attribution License, which permits unrestricted use, distribution, and reproduction in any medium, provided the original author and source are credited. 